\title{
H 107
}

\section{印刷作業環境におけるトルエン濃度測定法の検討}

○米原澄子 $*_{1}$ 、吉永久生 $*_{2}$ 、馬目佳信 $*_{2}\left({ }^{*} 1\right.$ 十一房印刷工業侏、*2 東京慈恵会医科大学)

<はじめに>

有機溶剤を使用する作業場では、労働衛生管理 のため法で定められた作業環境測定、特殊健康診 断が行なわれる。しかし当社が有するオフセット 印刷作業場のような非定常的作業環境において、 通常の定点測定のみで実際の作業環境を把握す るのは難しい。それは有機溶剤の発散が短時間、 間欠的であることに加え、個人間での作業方法が 職場全体の環境に及ぼす影響が少ないためであ る。そのためパッシブサンプラーを用いた個人暴 露量測定を加えることでより実際的な管理が可 能になることを我々はこれまで本学会で報告し てきたが、今回は当社における実例を報告する。

＜対象と方法 $>$

オフセット印刷（枚葉機）工場

A工場(1F) : $12 \mathrm{~m} \times 17 \mathrm{~m}$ 、印刷機 : 5 台 作業者：8名

B 工場 $(B 1 F) ： 12 \mathrm{~m} \times 17 \mathrm{~m}$ 、印刷機：7台 印刷作業者 : 10 名

今回は有機溶剂のうち対象をトルエンに絞っ て報告する。作業時間内である 9:00〜16:00（昼 休みを除く 7 時間)、呼吸器付近である作業者の 襟元にパッシブサンプラーを装着。その後二硫化 炭素で脱着し、GC/MS (ガスクロマトグラフ質量 分析計）で測定した。定点測定はパッシブサンプ ラーの装着日と同日、作業開始から 2.5 時間経過
した $11 ： 00$ にサンプリングバッグを使用し空気 を直接捕集した。尿中馬尿酸(HA)測定では作業終 了時に近い $16: 00$ に採尿した。

\section{<結果及び考察 >}

表から、定点測定の結果では両工場とも幾何平 均值が $15.4 \mathrm{ppm} 、 10.3 \mathrm{ppm}$ 、第一評価値が $50 \mathrm{ppm}$ 以下であり、この結果からは作業環境に問題はな いように見える。しかし個人暴露量測定では、作 業者の平均值が $\mathrm{A}$ 工場 $36.2 \mathrm{ppm} 、 \mathrm{~B}$ 工場 $36.8 \mathrm{ppm}$ であり、許容濃度の $50 \mathrm{ppm}$ を超える者も 3 名い た。このように、定点測定では問題が指摘されな いような作業場でも個人暴露量を測定すると時 間加重の要素が加味されて問題が明らかとなる 場合もある。その理由には、オフセット印刷作業 では同じ機械の作業者でも溶剤を使う者とそう でない者とで個人暴露量值に 1.5 倍の差がある程 濃度が局所的であり、さらに溶剂使用時間が短時 間、閒欠的であるため、定点測定值が作業場を代 表する值になりにくいことが挙げられる。また、 これら 3 名の中にはHA 值が分布 1 の者も含まれ、 逆に個人暴露量值 $40 \mathrm{ppm}$ 末満の者のうち 2 名が 分布 3 であるなど、HA 值と個人暴露量值に必ず しも相関は見られなかった。

以上、非定常的作業環境において十分な衛生管 理を行なうためには個人暴露量測定を加えるこ とが有用であると考えられる。

表.A 工場と $\mathrm{B}$ 工場における HA 值、定点測定值、個人暴露量值の測定結果

\begin{tabular}{l|c|c|c|c|c|c|c|c|c}
\hline & \multicolumn{3}{|c|}{$H A$ 測定值 } & \multicolumn{4}{c|}{ 定点測定值 } & \multicolumn{2}{c}{ 個人暴露量測定値 } \\
\cline { 2 - 10 } & 分布1 & 分布2 & 分布3 & $\mathrm{M}(\mathrm{ppm})$ & $\sigma$ & $\mathrm{E}_{\mathrm{A} 1}(\mathrm{ppm})$ & $\mathrm{E}_{\mathrm{A} 2}(\mathrm{ppm})$ & 平均値 & 50ppm以上 \\
\hline A工場 & 1 名 & 5名 & 2名 & 15.4 & 2.01 & 48.5 & 19.6 & $36.2 \mathrm{ppm}$ & 1名 \\
\hline B工場 & 6 名 & 4名 & 0名 & 10.3 & 1.96 & 31.1 & 12.9 & $36.8 \mathrm{ppm}$ & 2名 \\
\hline
\end{tabular}

